\title{
Investment Performance For Riverside Property Development: The Shore Malacca
}

\author{
Azlina Md. Yassin ${ }^{1}$, Haryati Shafiii ${ }^{2}$, Sharifah Meryam Shareh Musa ${ }^{2}$, Bayan Indera Rubaiah ${ }^{1}$ \\ 1. Department of Real Estate Management, Faculty of Technology Management and \\ Business, University Tun Hussein Onn Malaysia. \\ 2. Department of Construction Management, Faculty of Technology Management and \\ Business, University Tun Hussein Onn Malaysia. \\ azlina@uthm.edu.my
}

\begin{abstract}
This paper aims to determine the challenges in developing riverside property and to identify the investment performance of riverside property development in Malacca. The research was conducted within the case study area namely The Shore Malacca which built next to Malacca River. This riverside development (The Shore Malacca) not only included residential units but also commercial units. It is believed that this type of development is able to bring up the quality of that particular area which then causes the property price to increase. The results were based on the series of interviews conducted with selected respondent which are person directly involved with the development of The Shore Malacca, as well as reviewed several related documents. From the data, there were several challenges identified in developing riverside property in the case study area, and these challenges were then categorized under three category: minor, moderate and major challenges. Moreover, The Shore Malacca has the best investment performance in year 2015 with a highest occupancy rate and the worst investment performance in 2017 with the lowest number of occupied outlet units. This situation happened due to the shrink of economic and the low purchasing power of buyers in real estate market of Malacca. Therefore, this result will help the investor to make decision to investment in Malacca riverfront development and to enhance the economic value of riverfront areas. This research adopted qualitative research approach along the research process. The Shore Malacca was selected as a case study area. The results were based on the series of interviews conducted with selected respondent which are person directly involved with the development of The Shore Malacca, as well as reviewed several related documents. The results has identified several challenges while developing The Shore Malacca, and then categorized under three categories: minor, moderate and major challenges. The results also determined the Shore Malacca has the best investment performance in year 2015 with a highest occupancy rate and the worst investment performance in 2017 with the lowest number of occupied outlet units. This situation happened due to the shrink of economic and the low purchasing power of buyers in real estate market of Malacca. Therefore, this result will help the investor to make decision to investment in Malacca riverfront development and to enhance the economic value of riverfront areas. In this research, investment performance is seen from the business performance (operational) in the Shore Malacca. Since some information is considered confidential especially in terms of profit, the results was not viewed holistically, but were based on respondent justifications. Hopefully, this result will help the investor to make decision to investment in Malacca riverfront development and to enhance the economic value of riverfront areas. This research combines the study of real estate and investment
\end{abstract}

Investment Performance For Riverside Property Development: The Shore Malacca

Azlina Md. Yassin, Haryati Shafii, Sharifah Meryam Shareh Musa, Bayan Indera Rubaiah 
performance. Moreover, this research had employed series of interviews with respective stakeholders that directly involved in the riverfront projects.

Keywords: Challenges, Development, Investment, Property, Riverside

\section{INTRODUCTION}

In Malaysia, rivers make a huge contribution of social importance to global transportation; as an element in cultures and traditions, as a source of primary and secondary production, and for biodiversity (Yassin, Bond, \& McDonagh, 2011). For instance is Malacca River, which it flows through the middle of Malacca City in the state of Malacca which connected to the Straits of Malacca and act as a vital trade route during the heyday of Malacca Sultanate in the $15^{\text {th }}$ century. Since Malacca River gives thousands of benefits for economic development in Malacca, thus, riverside property development is a must from developers in order to give a new life or a new look to Malacca City. Clearly, Malacca River is a strategic and important source for world trade and regional development because it is vulnerable to social, political and natural disasters besides giving great opportunities for economic and social development.

According to (Guy \& Henneberry, 2004), developers are the key coordinator and catalyst for development. They are the nexus of the occupier, investment and development sectors in the property market as stated by (D'Arcy \& Keogh, 2008). They have a crucial role in interpreting the requirements of occupiers and investors and translating them into built form. This is because riverside property development requires special construction technology and skill from the developer as compared to the typical type of property development. Like The Shore Malacca, before it turns to a high-rise building, it is just a vacant land. From here, it involves the conversion of land-use functions which need to be take note by developers in term of legal challenges.

Furthermore,(Razali, Yassin, Mastor, \& Zainudin, 2014) highlighted that as similar to other developments, riverside property development requires the involvement of many parties that include the government, developers, private investors, community groups, tourists and recreationalist. The riverside development project is influenced by stakeholders. It is all about the partnership in riverside development. Government usually responsible for the whole riverside development process and that requires government involvement at every level, namely federal, state and the local authority. As an example, government has the responsibility in determining the theme and the sequence of process of any development. A proper planning of each development is vital for raising investor's confidence to invest in the riverside project(Yarnell, 1999). Therefore, the investment performance of riverside property in real estate market of Malacca is actually depending on how well the planning is and the performance of responsibility of stakeholders.

Thus, this paper aims to discover the challenges that need to be faced by the developer in developing riverside property development and also to identify the investment performance for riverside property in Malacca.

\section{LITERATURE REVIEW AND HYPOTHESES DEVELOPMENT}

\section{A. Investment}

According to Akrani (2011), investment gives the meaning of purchase of financial assets. While investment goods are those goods, which are used for further production. Investment implies the production of new capital goods, plants and equipment.

In the financial sense, this includes the purchase of bonds, stocks or real estate property. Additionally, the constructed building or other facility used to produce goods can be seen as an investment. An investment can be happened in an action of the hopes of raising future revenue. Choosing

Investment Performance For Riverside Property Development: The Shore Malacca

Azlina Md. Yassin, Haryati Shafii, Sharifah Meryam Shareh Musa, Bayan Indera Rubaiah 
to pursue additional education can be considered as an investment also, as the goal is to increase knowledge and improve skills in the hopes of producing more income.

\section{B. River}

According to YPTE (2017), three quarters of planet earth's surface is covered by salt water which includes the seas and oceans. The quarter of the surface which is land holds more water-this is fresh and will be found in rivers, lakes or underground. River is a natural stream of freshwater that is larger than a brook or creek. Rivers are normally the main channels or largest tributaries of drainage systems. Basically, there are four types of river which included permanent rivers, periodic rivers, episodic rivers and exotic rivers.

Rivers have been used for multiple purposes such as, for food, as a defensive barrier and for human settlement. Human controls the river just like the management of a river. A good river management should have the river management aspects like maintaining vegetation, clearing obstructions and preventing plants and other objects, such as logs, from blocking waterways, gravel management in some areas, erosion control and pest control. Good river management practice helps protect the property and land from damage.

\section{Property}

Property is defined as anything that is owned by a person or entity (Gerald, 2005). Property is also defined as things and rights that can be owned or that have a money value. Property also signifies a beneficial right to to a thing. In short, property is either realty, which comprises freehold land, or personally, which comprises everything else, including leasehold land and held on trust for sale whereas pure personally is the term used to denote chattels and other forms of personal property having no connection with land. Property can be classified into real property, personal property, community property, separate property and public property as explained in Table 1 below:

Table 1: Classification Of Property

\begin{tabular}{c|cl}
\hline Classification & \multicolumn{1}{c}{ Detail } \\
\hline Real property & $\bullet \begin{array}{l}\text { Refers to any tangible landed property or incorporeal hereditament. } \\
\text { - }\end{array}$ & $\begin{array}{l}\text { Consists of all land, structures, firmly attached and integrated equipment (such } \\
\text { as light fixtures or a well pump), anything growing on the land and all } \\
\text { "interests" in the property which may be the right to future ownership } \\
\text { (remainder), right to occupy for a period of time (tenancy), the right to drill for } \\
\text { oil, the right to get the property back if it is no longer used for its current } \\
\text { purpose (such as use for a hospital, school or city hall), } \\
\text { use of airspace (condominium) or an easement cross another properties. }\end{array}$ \\
\hline Personal property & $\bullet \begin{array}{l}\text { Personal property can include any asset other than real estate. It also known as } \\
\text { movable property, movables, and chattels. }\end{array}$ \\
\hline Community property & $\begin{array}{l}\text { The distinguishing factor between personal property and real estate is that } \\
\text { personal property is movable; that is, the asset is not fixed permanently to one } \\
\text { location as with real property, such as land or buildings. Examples of personal } \\
\text { property include vehicles, furniture, boats, and collectibles. }\end{array}$ \\
\hline Separate property & $\begin{array}{l}\text { Community property is known as "marital property". Community property } \\
\text { issues can arise in divorce proceedings and after the death of a spouse. } \\
\text { This can include items of value such as cars, furniture, paintings and family } \\
\text { homes, but may also include intangible assets like stocks, bonds, legal title and } \\
\text { also debt. }\end{array}$ \\
\hline
\end{tabular}

Investment Performance For Riverside Property Development: The Shore Malacca

Azlina Md. Yassin, Haryati Shafii, Sharifah Meryam Shareh Musa, Bayan Indera Rubaiah 


\begin{tabular}{|c|c|}
\hline & $\begin{array}{l}\text { separate property only includes property that was owned by either spouse prior } \\
\text { to the marriage, an inheritance received by the husband or wife (either before } \\
\text { or after the marriage), a gift received by the husband or wife from a third party } \\
\text { (your mother gave you her diamond ring) and payment received for the pain } \\
\text { and suffering portion in a personal injury judgment. } \\
\text { - All other property that is acquired during the marriage is usually considered } \\
\text { marital property, regardless of which spouse owns the property or how the } \\
\text { property is titled. }\end{array}$ \\
\hline Public property & $\begin{array}{l}\text { - Public property is defined as the property that is dedicated to public use and is } \\
\text { a subset of state property. } \\
\text { - The term may be used either to describe the use to which the property is put, or } \\
\text { to describe the character of its ownership. } \\
\text { - This is in contrast to private property, owned by an individual person or } \\
\text { artificial entities that represent the financial interests of persons, such } \\
\text { as corporations. }\end{array}$ \\
\hline
\end{tabular}

\section{Property Development}

Land development is best defined "as any change in the original alienated land, contrary to what was already approved by the State Authority upon alienation"(Jaafar, 2009). More specifically, the Town and Country Planning Act, 1976 (Act 172) looked at developments itself, "as the carrying out of any building, engineering, mining, industrial or other similar operation in, on, over, or under land, or making of any material change in the use of any building or other land, or the subdivision or amalgamation of lands".

Specifically, property development refers to any development of project on a piece of land with associated cost (own or via financier/ loan), managing the project from the very beginning till completion, and lastly handing over of project to the purchasers or users via leasing or other means. The development process is delicate due to involvement of many parties/ stakeholders and thus having high degree of associated risks. The objective of property development is just as simple as to expose on knowledge and understanding of systems, practices and processes as well as physical planning aspects related to property development.

\section{E. Development Control}

Development control is the process of determining planning applications submitted by individuals and commercial developers. It aims to ensure that development is in accordance with the Local Plan and is carried out in the best interests of the general public and the area. The physical characteristics of the subject land and surrounding land, such as topography, geology and soil type, vegetation cover, and drainage patterns and so on are also important considerations in assessing and evaluating proposals.

Development control has the function to regulate land use and development in order to ensure that all land use and development takes place at an appropriate time and place and in a form and manner that conforms to a pre-determined set of policies or standards (Rafftcliffe, 2004).

\section{F. $\quad$ Important Aspects In Property Development Management}

A good property development for sure it must has a good property development management. Therefore, there are few essential aspects that need to be taken into consideration in order to have a high quality of property development management. Figure 1 shows the important aspects in property development management.

Investment Performance For Riverside Property Development: The Shore Malacca 


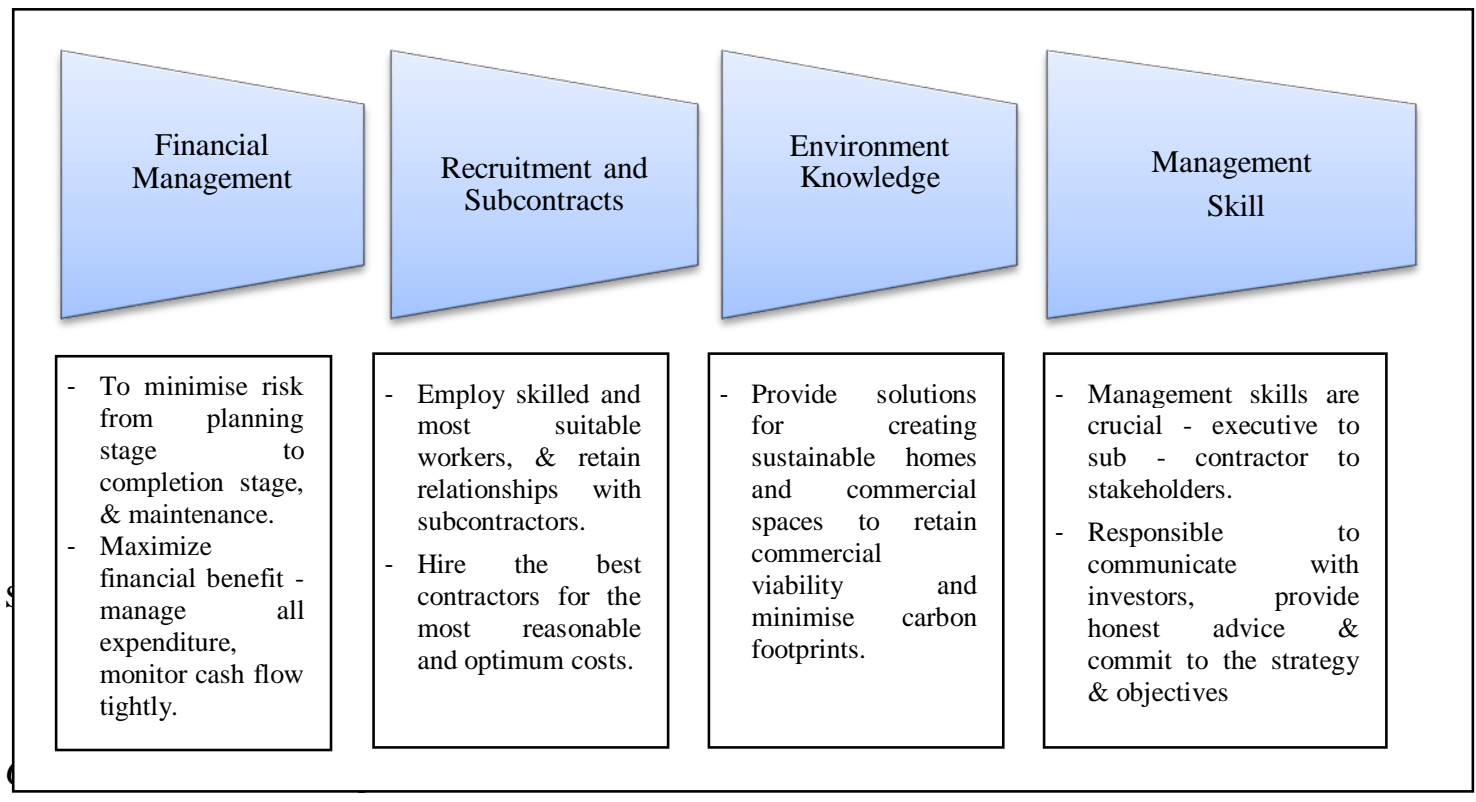

Waterfront is defined as the zone of interaction between a city and a river. In Malaysia, waterfront developments were established when the country was first settled, mainly as a transport route and for trading purpose. Waterfront development getting more and more urbanised and commercialised nowadays. From here, it demonstrates the importance of waterfront development.

Waterfront and waterfront developments have several expressive and varying interpretations due to characteristics of sites and cities. Moreover, there are researchers see waterfront as the water's edge in cities and towns of all sizes and the water body may be a river, lake, ocean, bay, creek, or canal.

According to (Md. Yassin, Eves, \& Mcdonagh, 2010), a more detailed definition about riverfront development was described as the interface point where land and water meet, between approximately 200 to 300 meters from the water line and 1 to $2 \mathrm{~km}$ to the land site and also takes in land within 20 minutes walking distance. In the development context, waterfronts were seen as a land to be reclaimed from water in order to create an extension of existing city centres.

\section{H. Riverside Property}

Obviously, riverside property means any land or building that built along the edges of or next to a river. In a close distance to river, this type of property actually has a more high risk than those normal landed properties that located far away from the river. Thus, it is expected that it is more challenging in developing riverside property as compared to other type of property development. 


\section{Elements for Successful Planning of Riverside Property Development}

A successful riverside development must share the same principles and functions. There are some fixed elements in order to achieve specific aims of a successful riverside property development. Therefore, (Torre, 1989) identified 10 elements recommended to be taken into consideration while planning a waterfront development, as presented in Table 2 below.

\section{Table 2: Elements for Waterfront Development}

\begin{tabular}{|c|c|}
\hline Element & Description \\
\hline Theme & $\begin{array}{l}\text { Themes are designed in the initial stages, mainly to control future spatial } \\
\text { analysis, land use materials, scale and meaning. Determined after several } \\
\text { considerations like climate, layout, design, land use of the development, } \\
\text { project's culture and history. }\end{array}$ \\
\hline Image & $\begin{array}{l}\text { The implementation of the theme would create the image. Image could } \\
\text { give a perception of the future waterfront project and good images have } \\
\text { become benchmarks for other projects. }\end{array}$ \\
\hline Authenticity & $\begin{array}{l}\text { Authenticity, from the word authentic, means undisputed origin or } \\
\text { genuine (Concise Oxford English Dictionary, 2009). Maintaining } \\
\text { authentic value of the waterfront area and the surrounding area is } \\
\text { important for a successful waterfront project }\end{array}$ \\
\hline Function & $\begin{array}{l}\text { Pedestrian access to a lively outdoor eating area and entertainment centre } \\
\text { gives visitors the chance to enjoy the water environment along with the } \\
\text { convenient services for the residential and working districts. }\end{array}$ \\
\hline $\begin{array}{l}\text { Public perception } \\
\text { of need }\end{array}$ & $\begin{array}{l}\text { The combination of theme, image, authenticity, environment and } \\
\text { financial considerations should also include public consideration, to } \\
\text { avoid environmental problems. }\end{array}$ \\
\hline $\begin{array}{l}\text { Financial } \\
\text { feasibility }\end{array}$ & $\begin{array}{l}\text { A waterfront is considered feasible once it is packaged, designed, } \\
\text { promoted, managed and operated effectively. The key fundamental is a } \\
\text { waterfront concept that leads the financial assessment not the reverse. }\end{array}$ \\
\hline $\begin{array}{l}\text { Environmental } \\
\text { approvals }\end{array}$ & $\begin{array}{l}\text { Inter-agency meetings are required sequentially to determine the } \\
\text { environmental impact of the waterfront development. Approval from } \\
\text { various agencies is required. As a rule of thumb every acre of impact } \\
\text { needs two acres of mitigation and must be provided and for the most part, } \\
\text { enhancement does not count. }\end{array}$ \\
\hline $\begin{array}{l}\text { Construction } \\
\text { technology }\end{array}$ & $\begin{array}{l}\text { Use cost-effective and environmental friendly materials for the } \\
\text { construction of riverside properties. }\end{array}$ \\
\hline $\begin{array}{l}\text { Effective } \\
\text { management }\end{array}$ & $\begin{array}{l}\text { Proper management must include a number of different sources of } \\
\text { expertise, and coordination between them is very important, no matter } \\
\text { whether for public or private waterfront development. }\end{array}$ \\
\hline $\begin{array}{l}\text { Beginning } \\
\text { project }\end{array}$ & $\begin{array}{l}\text { Combining all the elements listed above will result in a comprehensive, } \\
\text { balanced and self-contained waterfront project. } \\
\text { Updated current information on waterfront areas is needed. } \\
\text { Participation from all responsible groups including the public is } \\
\text { important at every stage of development. } \\
\text { Organisational management; establish a waterfront committee and } \\
\text { include representatives from the government authority to make the }\end{array}$ \\
\hline
\end{tabular}

Investment Performance For Riverside Property Development: The Shore Malacca

Azlina Md. Yassin, Haryati Shafii, Sharifah Meryam Shareh Musa, Bayan Indera Rubaiah 


\begin{tabular}{l|l}
\hline Element & \multicolumn{1}{c}{ Description } \\
\hline process effective. Maintain momentum; create anticipation and \\
marketing and then maintaining momentum until project completion is \\
important. \\
Plan an opening celebration; celebration illustrates a commitment to the \\
development.
\end{tabular}

Source: (Torre, 1989)

\section{J. $\quad$ Principles For Sustainable Riverside Development In Malaysia}

In order to maintain an economically viable of riverfront, (Md. Yassin, Bond, \& Mcdonagh, 2012) recommended several important principles that need to take into account while developing riverside property development. The said principles are listed in Table 3 below:-

\section{Table 3: Principles For Sustainable Riverfront Development In Malaysia}

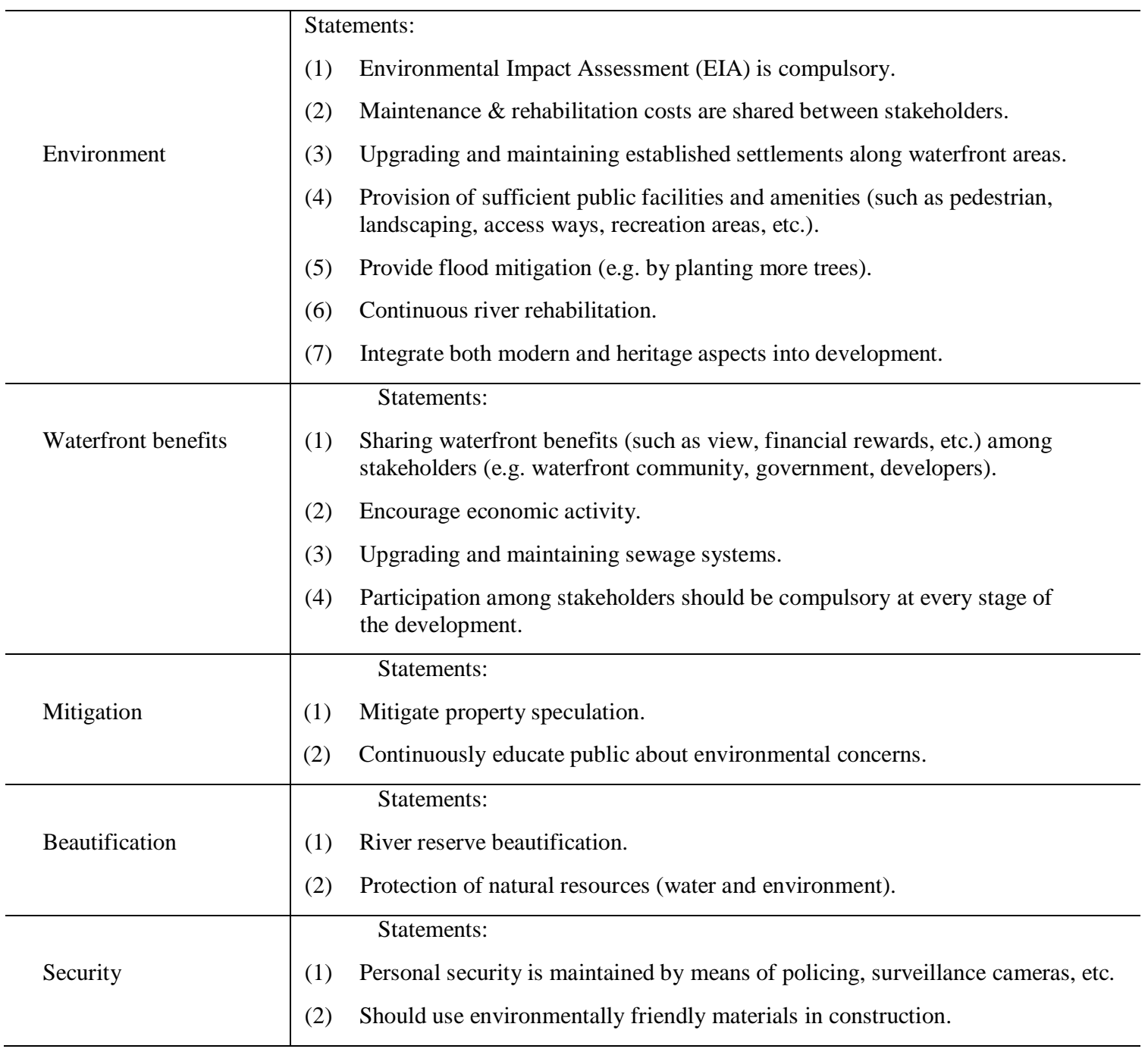

Investment Performance For Riverside Property Development: The Shore Malacca

Azlina Md. Yassin, Haryati Shafii, Sharifah Meryam Shareh Musa, Bayan Indera Rubaiah 


\begin{tabular}{c|c}
\hline Type of development & Statement: \\
& (1) Restrict type of development. \\
\hline
\end{tabular}

Source: (Md. Yassin et al., 2012)

\section{K. Issues Of Riverside Property Development}

Alike other development types, running a riverside property development also involved some issues, and the Issues exist normally at the beginning and during the process of construction of riverside properties. These issues are including pollution, environmental concern, natural resources, and design control.

\section{(i) Pollution}

Pollution issues which include water pollution, noise pollution and air pollution are considered the major issues arise on riverside property development. Especially for water pollution, this issue was happened is due to undergo high rise property development close to water body without proper mitigation.

\section{(ii) Flooding Risk and Environmental Concern}

The risk of flooding increases significantly with rivers that have little or no flood control. Even if a river never floods, flowing water is still destructive to the land over which it passes which could lead to extensive property damage.

\section{(iii) Natural Resources vs Urban Amenity}

Waterfronts are special urban areas in a city (Hossain, 1984). These areas offer unique opportunities for providing cultural and recreational public amenities to urban life. The important difference between water as a natural resource and water as an urban amenity lies in the relationship of water with the urban form.

\section{(iv) Design Control}

Design control is within the planning system that operates at two levels, covering, first, aesthetic control and second urban design and townscape which will be considered in turn.

\section{METHODOLOGY}

This research adopted qualitative research approach along the research process. It is to solve research problem systematically and scientifically along with the logic behind them (Kothari, 2004). It comprises the theoretical analysis of the body of methods and principles associated with a branch of knowledge. The results were based on the data collected through interviews with respective respondents within the case study areas, as well as observation and review of related documents.

\section{A. The Case Study Area - The Shore Malacca}

The Shore Malacca is situated in Jalan Persisiran Bunga Raya within the area of Malacca City Centre. The Shore is just a short drive away from the heart of Malacca's historical sites, the well-known Jonker Street and Chinatown where tourists throngs. At the current stage, The Shore is the first leading high-rise building in Malacca. The Shore is completed build in 2015 with the area of 3.1 acres. It is developed by a private developer. It is a freehold, luxury mixed development that houses within its grounds 3 towers of luxury serviced residences, a 4-star hotel, and a lifestyle shopping mall with F\&B outlets.

Investment Performance For Riverside Property Development: The Shore Malacca 
The Shore is fully equipped with high class facilities. Housed on the 9th floor of The Shore, the facilities deck incorporates extensive tropical landscaping into their leisure pool. And overlooking this serenity is a fully equipped gymnasium. A children's fun pool, lap pool, jacuzzi pool complete the creature comforts of the luxury residences. There is also a chic roof-top Sky Lounge where you can sip cocktails as you take in the stunning sunset over The Straits of Malacca, while the city of Malacca is quite literally at your feet. In short, from Figure 2 of Malacca River Map, The Shore is a very attractive tourist hotspot with a nice view of Malacca River.

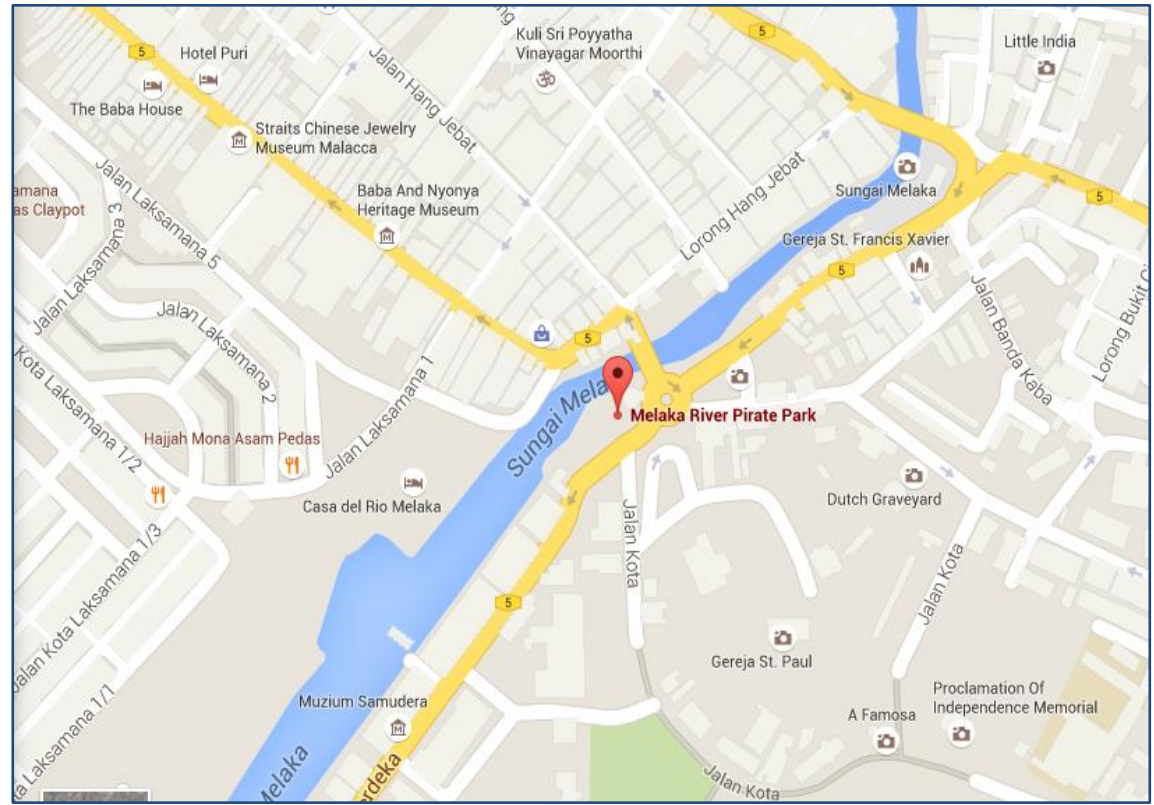

Figure 2: Location Plan To The Malacca Shore

\section{RESULTS AND DISCUSSION}

The findings of the study were based on the interviews and reviewed several related documents. The collected data were then interpreted by using Qualitative Data Analysis Technique - Thematic Network Analysis (Attride-Stirling, 2001) to ensure that the data collected meet the objectives of the study.

\section{A. Challenges In Developing Riverside Development - The Shore Malacca}

From the interview, the challenges in developing The Sore Malacca can be summarises and as presented in the Table 4 below.

Table 4: Challenges in Developing Riverside Development - The Shore Malacca

\begin{tabular}{l|l}
\hline \multicolumn{1}{c|}{ Challenge } & \multicolumn{1}{c}{ Details } \\
\hline Soil matter & $-\begin{array}{l}\text { Land is not stable as The Shore Malacca is built right beside to Malacca River. } \\
\text { Developer used up a lot of shift piles and casting works - to prevent the inflow of } \\
\text { water because the soil is very soft unlike the normal land for the landed property } \\
\text { development. }\end{array}$ \\
\hline Working time & $-\begin{array}{l}\text { Construction work operated within 24 hours non-stop and requires numbers of } \\
\text { construction workers in the site (shift) - time management/planning is crucial. }\end{array}$ \\
\hline
\end{tabular}

Investment Performance For Riverside Property Development: The Shore Malacca

Azlina Md. Yassin, Haryati Shafii, Sharifah Meryam Shareh Musa, Bayan Indera Rubaiah 


\begin{tabular}{|c|c|}
\hline Challenge & Details \\
\hline $\begin{array}{l}\text { Consultation and } \\
\text { teamwork }\end{array}$ & $\begin{array}{l}\text { - Less cooperation between parties involved (directly and indirectly) in the } \\
\text { construction had caused delay and late completion of the project. For example, late } \\
\text { confirmation / approval for certain cases. }\end{array}$ \\
\hline $\begin{array}{l}\text { Building technology } \\
\text { / machinery }\end{array}$ & $\begin{array}{l}\text { - Building technology is an unavoidable challenges in riverside property } \\
\text { development - big challenge in applying the high-tech in the construction of high } \\
\text { rise building in term of the complexity of building technologies application. } \\
\text { - Choices of machinery or equipment like crane is important as it gives the big } \\
\text { impact to the construction performance - time saving, safety and cost }\end{array}$ \\
\hline $\begin{array}{l}\text { Government } \\
\text { legislation }\end{array}$ & $\begin{array}{l}\text { - Malacca local government has set some critical law, rule and regulation for the } \\
\text { development of high rise building - to ensure that the height of a building do not } \\
\text { block the way of aeroplane. } \\
\text { - In Malacca, especially in urban area, any building that is built more than } 43 \text { floors } \\
\text { (equivalent to } 150 \text { meters height) is restricted, unless it is out of the city like rural } \\
\text { area. }\end{array}$ \\
\hline Cost of development & $\begin{array}{l}\text { - The Shore Malacca cost about } 600 \text { millions and without financial assistance from } \\
\text { financial institution. } \\
\text { - Therefore, financial management must be taken seriously to avoid an abandoned } \\
\text { project in the future. }\end{array}$ \\
\hline
\end{tabular}

\section{B. The Investment Performance For Riverside Property Development In Malacca (The Shore Malacca)}

From the results, the investment performance for The Shore Malacca can be measured by two components; rental rate and occupancy rate.

\section{Rental Rate}

Every unit in The Shore Malacca have different size (counted in square feet) and different uniqueness. In short, the rental rate for each unit is determined by the size of the unit and the specialty and uniqueness of the lot itself. In general, every outlet unit in The Shore Malacca will have differences in their contract with the management body like the penalties in term of move in and out. Outlet unit has the range of rental between RM5.00 to RM 10.00 per square feet. For contract, management body will not lower down the rental for tenants even tenants are willing to continue the new term of contract, it is either they maintain the rental or they rise up the rental. Anyhow, in order to enhance its investment performance, The Shore Malacca need to organize more events to make the mall to an active status or to approach tenants themselves.

\section{Occupancy Rate}

Table 5 and Table 6 below present the list of occupied outlet units and the occupied outlet units in The Shore Malacca as at October 2017.

Table 5- List Of Occupied Outlet Unit In The Shore Malacca

\begin{tabular}{c|l|l}
\hline Level & \multicolumn{2}{|c}{ Occupied Outlet Units } \\
\hline Ground Floor & Seoul Garden & Rock Bottom Kitchen\& Bar \\
& Nando's Restaurant & Switch Mac Book \\
\hline
\end{tabular}

Investment Performance For Riverside Property Development: The Shore Malacca 


\begin{tabular}{|c|c|c|}
\hline Level & \multicolumn{2}{|c|}{ Occupied Outlet Units } \\
\hline & $\begin{array}{l}\text { JSCCA Boutique } \\
\text { ELLE Boutique } \\
\text { TISSOT Swiss Watch } \\
\text { Sothys Paris Skin Products } \\
\text { Ice Watch } \\
\text { Pandora Jewellery } \\
\text { Habib Jewellery }\end{array}$ & $\begin{array}{l}\text { The Body Shop } \\
\text { SASA Cosmetic } \\
\text { Aeon Wellness } \\
\text { Guy Laroche } \\
\text { TANGS } \\
\text { Burger Giler Power } \\
\text { Starbucks Coffee }\end{array}$ \\
\hline $1^{\text {st }}$ Floor & $\begin{array}{l}\text { Thai Odyssey Massage \& Spa } \\
\text { Centre } \\
\text { Oriks Cosmetic } \\
\text { Sushi Zanmai } \\
\text { Krispy Bites } \\
\text { Greenie Fashion } \\
\text { Sox World }\end{array}$ & $\begin{array}{l}\text { Prestige Houseware } \\
\text { Toy Musuem } \\
\text { aL-ikhsaN Sports Boutique } \\
\text { TANGS } \\
\text { Factory Outlet Store (F.O.S) } \\
\text { Cael Deon }\end{array}$ \\
\hline $2^{\text {nd }}$ Floor & $\begin{array}{l}\text { The Shore Oceanarium } \\
\text { Herba Drink } \\
\text { U Love Enterprise Beverage } \\
\text { Gift Tower } \\
\text { Oceanarium Gift Shop } \\
\text { Hippopo Baby Spa\& Wellness }\end{array}$ & $\begin{array}{l}\text { SIM Play City Enterprise\& Café } \\
\text { Mr D.I.Y } \\
\text { Macam-macam Souvenir Shop } \\
\text { The Shore 3D Interactive Park } \\
\text { The Rooms Souvenir Shop }\end{array}$ \\
\hline $3^{\text {rd }}$ Floor & $\begin{array}{l}\text { E-Trend Convenient Store } \\
\text { La Flor Enterprise Florist } \\
\text { Yoong Yoong Biz Hair Product } \\
\text { Center }\end{array}$ & $\begin{array}{l}\text { KL Remit Exchange } \\
\text { Creer Hair\& Makeup Saloon } \\
\text { Car Wash }\end{array}$ \\
\hline
\end{tabular}

Table 6 - The Occupied Kiosk Unit In The Shore Malacca

\begin{tabular}{c|l}
\hline Level & \multicolumn{1}{c}{ Occupied Kiosk Units } \\
\hline Ground Floor & Haagen-Dazs \\
& Tealive Beverage \\
& BOOST Juice \\
& The Shore Sales Gallery \\
& The Shore Sales Booth \\
& Toy Station \\
& Sky Deck Ticketing Counter \\
\hline $1^{\text {st }}$ Floor & Hotlink Telecommunication \\
\hline
\end{tabular}


Table 7 below summarises the occupancy rates for the units in The Shore Malacca for the past three years. This information will helps to determine the investment performance of The Shore Malacca based on the occupancy rate.

Table 7- Occupancy Rate in Year 2015 to 2017

\begin{tabular}{l|c|c|c|c}
\hline \multirow{2}{*}{ Description } & \multirow{2}{*}{$\begin{array}{c}\text { Number } \\
\text { of Unit }\end{array}$} & & \multicolumn{3}{|c}{ Occupancy Rate (\%) } \\
\cline { 3 - 5 } & & 2015 & 2016 & 2017 \\
\hline Occupied Outlet Units & 58 & 71.60 & 72.84 & 59.26 \\
\hline Occupied Kiosk Units & 8 & 9.88 & 9.88 & 9.88 \\
\hline $\begin{array}{l}\text { Unoccupied Units (Empty } \\
\text { Units) }\end{array}$ & 15 & 18.52 & 17.28 & 30.86 \\
\hline Total Units & 81 & 100 & 100 & 100 \\
\hline
\end{tabular}

Overall, investment performance towards The Shore Malacca shopping mall demonstrates a downward trend. This is due to the huge increment in the unoccupied units and a minor increment in the occupied outlet units. In this situation, it figured out the ineffectiveness and inefficiency of management body in renting out their shopping mall units and at the same time it indicates the shrink of economic in the market. This can be explained with the less number of tenants at The Shore Malacca shopping mall and a low purchasing power from the consumers.

Moreover, along these three years, profit gained not only from the hotel units but also a big contribution from the rental of ballrooms and conference facilities. Furthermore, along these years of operation, the weakest business performance is at the beginning of the operation of The Shore Hotel and Residences. This happened because of the incompletion of the facilities and services at The Shore Hotel and Residences plus it is still a new development at that period. The next reason is that staffs are insufficient and hence it affects the progress of work and lastly influences the business performance. The influence on business performance lower down the confidence level of potential investors, thus, investment performance can be diminished.

Last but not least, investment performance of The Shore Malacca can be measured in the gaining of awards. Along this years, The Shore Malacca gained certain awards like ISO 9001: 2000 Quality Management Systems Certification, Malacca tallest building, Malacca first best commercial landscape architecture project awarded by Asia Pacific Property Awards, Malacca first building tower with full heights LED lighting/screen on facade, sky lounge/observatory deck at level 43 (163 meters above sea level), 60,000 square feet of water play area \& facilities at level 9, and many more.

\section{CONCLUSION}

This paper research was carried out to determine the challenges and the investment performance in riverside property development in Malacca - The Shore Malacca. The study has revealed several challenges while developing The Shore Malacca, namely soil matter, financial constraint, legislation and many more. In regards to the investment performance towards The Shore Malacca, the results were based on the two components namely occupancy rate and rental rate.

In addition, this performance is measured through the calculation of occupancy rate in shopping gallery for occupied outlet units, occupied kiosk units and unoccupied units. Besides, occupancy rate and rental rate in service apartment, hotel and residences are also discovered. Based on these two components, the results determined that the investment performance for The Shore Malacca is on downward trend. This is due to several factors such as bad economic situation lately and competition from other riverside development nearby.

Investment Performance For Riverside Property Development: The Shore Malacca 
In a nutshell, developer need to take all the challenges into account and the management body need to be more creative and competitive for the future riverside property development. Only through this, a high quality and an excellent investment performance of riverside property development can be produced in Malacca.

\section{ACKNOWLEDGMENTS}

We are grateful for the RMC, UTHM for the publication opportunity and Ministry of Higher Education for the Fundamental Research Grant Scheme (FRGS).

\section{REFERENCES}

Attride-Stirling, J. (2001). Thematic networks: an analytic tool for qualitative research. Qualitative Research, 1(3), 385-405.

D’Arcy, amonn, \& Keogh, G. (2008). The Market Context of Property Development Activity. In Development and Developers: Perspectives on Property. https://doi.org/10.1002/9780470757192.ch2

Guy, S., \& Henneberry, J. (2004). Economic structures, urban responses: framing and negotiating urban property development. City Matters: Competitiveness, Cohesion and Urban Governance, 217-236.

Hossain, M. I. (1984). Urban waterfront: problems and potentials of Boston. Massachusetts Institute of Technology.

Jaafar, N. N. N. (2009). Land development process in Malaysia. Kuala Lumpur, Malaysia: Nilai Harta Consultant Sdn. Bhd, retrieved.

Md. Yassin, A., Bond, S., \& Mcdonagh, J. (2012). Principles for Sustainable Riverfront Development for Malaysia. Journal of Techno-Social.

Md. Yassin, A., Eves, C., \& Mcdonagh, J. (2010). An Evolution of Waterfront Development in Malaysia. In 16th Pacific Rim Real Estate Society Conference.

Razali, M. N., Yassin, A. M., Mastor, S. H., \& Zainudin, A. Z. (2014). Sustainability in waterfront development in Malaysia: Barrier to achieving best practices of waterfront development. Energy and Sustainability, 186, 421-430.

Torre, L. A. (1989). Waterfront development. Van Nostrand Reinhold.

Yarnell, P. (1999). Port administration and integrated coastal management under the canada marine act in vancouver, british columbia, Canada. Coastal Management. https://doi.org/10.1080/089207599263758

Yassin, A. B. M., Bond, S., \& McDonagh, J. (2011). Waterfront development in Malaysia: Do we have sustainable governance? Pacific Rim Property Research Journal. https://doi.org/10.1080/14445921.2011.11104338

Investment Performance For Riverside Property Development: The Shore Malacca 